\title{
Natural Compounds from Herbs that can Potentially Execute as Autophagy Inducers for Cancer Therapy
}

\author{
Shian-Ren Lin ${ }^{1}$ (D), Yaw-Syan Fu ${ }^{2}$, May-Jywan Tsai ${ }^{3,4}$, Henrich Cheng ${ }^{3,4}$ and \\ Ching-Feng Weng $1, *$ iD \\ 1 Department of Life Science and Institute of Biotechnology, National Dong Hwa University, \\ 97401 Hualien, Taiwan; d9813003@gms.ndhu.edu.tw \\ 2 Department of Biomedical Science and Environmental Biology, Kaohsiung Medical University, \\ 807 Kaohsiung city, Taiwan; m805004@kmu.edu.tw \\ 3 Neural Regeneration Laboratory, Department of Neurosurgery, Neurological Institute, Taipei Veterans \\ General Hospital, 11221 Taipei, Taiwan; mjtsai2@vghtpe.gov.tw (M.-J.T.); hc_cheng@vghtpe.gov.tw (H.C.) \\ 4 Center for Neural Regeneration, Neurological Institute, Taipei Veterans General Hospital, \\ 11221 Taipei, Taiwan \\ * Correspondence: cfweng@gms.ndhu.edu.tw; Tel.: +886-3-863-3637; Fax: +886-3-863-0255
}

Received: 26 May 2017; Accepted: 27 June 2017; Published: 1 July 2017

\begin{abstract}
Accumulated evidence indicates that autophagy is a response of cancer cells to various anti-cancer therapies. Autophagy is designated as programmed cell death type II, and is characterized by the formation of autophagic vacuoles in the cytoplasm. Numerous herbs, including Chinese herbs, have been applied to cancer treatments as complementary and alternative medicines, supplements, or nutraceuticals to dampen the side or adverse effects of chemotherapy drugs. Moreover, the tumor suppressive actions of herbs and natural products induced autophagy that may lead to cell senescence, increase apoptosis-independent cell death or complement apoptotic processes. Hereby, the underlying mechanisms of natural autophagy inducers are cautiously reviewed in this article. Additionally, three natural compounds-curcumin, 16-hydroxycleroda-3,13-dien-15,16-olide, and prodigiosin-are presented as candidates for autophagy inducers that can trigger cell death in a supplement or alternative medicine for cancer therapy. Despite recent advancements in therapeutic drugs or agents of natural products in several cancers, it warrants further investigation in preclinical and clinical studies.
\end{abstract}

Keywords: autophagy inducer; autophagy inhibitor; natural compound; cancer therapy

\section{Introduction}

Cancer is a group of diseases involving out-of-control of cell growth due to the accumulation of defects, or mutations, in their DNA and with an impendence to invade or spread to other parts of the body [1]. In 2015, about 90.5 million people were diagnosed with cancer [2]. About 14.1 million new cases occur each year (not including skin cancer other than melanoma) [3]. Consequently, it causes about 8.8 million (15.7\%) human deaths [4]. Anti-cancer drugs including 5-fluorouracil (5-FU), cisplatin, etoposide, paclitaxel, and doxorubicin are commonly used to treat various cancers, such as cisplatin and doxorubicin in ovarian cancer, 5-FU in colon and gastric cancer, paclitaxel and doxorubicin in breast cancer, and etoposide in small-cell lung cancer. However, these chemotherapeutic agents have evident side effects such as nausea, vomiting, loss of appetite, decreased immunity, oral ulcers, and other adverse effects [5]. In general, the anti-cancer drugs, such as cisplatin and doxorubicin favor abnormal triggering via programmed cell death (PCD) such as apoptosis, necrosis, necroptosis, and autophagy in normal cells as well as abolishing inflammation of damaged cells. Remarkably, apoptosis and 
autophagy are traditionally considered the most prominent cell death or cell death-related mechanisms for anti-cancer drug discovery [6,7].

In contrast to apoptosis, autophagy is a homeostatic process, and is one of the earliest responses to pharmacologically active compounds lead to ultra-structural perturbations; changes in membrane composition, cytoskeleton integrity, alterations of the endoplasmic reticulum, mitochondria and nucleus all result in the formation of morphological alterations. This biological process of autophagy is designated as type II PCD, and has several features, such as removing damaged or excessive proteins, utilization by various types of cells to maintain cellular homeostasis, high conservation across different types of mammalian cells, and is a potentiated cancer type preceding cell death. Moreover, autophagy can relieve tumor cells from nutrient and oxidative stress during a rapid expansion of a cancer. Excessive and sustained autophagy may lead to cell death and tumor shrinkage. Interestingly, autophagy also occurs in cancer cells and exerts anti-survival or pro-survival effects depending on stimuli, nutrients, and context.

\section{The Significance of Autophagy in Cancer}

Autophagy is an important process in many functions such as maintaining protein quality, presenting antigens, responding to endoplasmic reticulum (ER) stress, and supplying energy [8]. These functions represent a stress in cells so that autophagy usually links to degenerative diseases like dementia and Parkinson's disease [9]. There are two opposite mechanisms for autophagy in cancer development. Firstly, autophagy can clean up damaged organelles or protein accumulations and further activate programmed cell death when the cell is severely damaged. This anti-cancer mechanism provides another checkpoint to avoid tumorigenesis. On the other hand, autophagy also affords a proportional way of overcoming chemotherapeutic drugs and a low energy state. Autophagy could be activated by ER stress and some reactive oxygen species (ROS), inducing chemotherapeutic drugs like cisplatin and doxorubicin, where it can assist cancer stem cells in cleaning up ROS-damaged proteins [10]. Autophagy, a catabolic degradation process via lysosomes, plays an important role in tumorigenesis and cancer therapy.

\subsection{Natural Autophagy Inhibitor from Herbs}

Currently, many herbs, including Chinese herbs, have been applied as cancer treatments to complement and act as alternative medicines, supplements, or nutraceuticals to dampen the aforementioned problems. It has been shown in the literature that many anti-cancer natural compounds and extracts could initiate autophagy in tumor cells. As summarized in this paper, tumor suppressive actions of natural product-induced autophagy may lead to cell senescence, provoke apoptosis-independent cell death, and complement apoptotic cell death by robust or target-specific mechanisms. Notably, natural compounds are fundamental for pharmacological treatments, and more than $50 \%$ of all anti-cancer drugs are of natural origins, or at least derived from scaffolds present in nature. Emerging research shows that molecules of natural origins are useful for preventive and therapeutic purposes by targeting essential hallmarks and enabling described characteristics. Moreover, natural compounds can change the differentiation status of selected cell types. In the past decade, some autophagy-related inducers and inhibitors have been extensively investigated. Of note, some autophagy inhibitors including 3-methyladenine (3-MA), pepstatin A, bafilomycin A1, and betulinic acid have been well studied, and have been applied as suppressors to examine the modality of autophagy formation in autophagy research [11]. Curiously, other natural autophagy inhibitors have also been elucidated as: (1) Matrine, a natural compound extract used in traditional Chinese medicine, can modulate the maturation process of lysosomal proteases in gastric cancer cell line (SGC-7901) cells [12]; (2) Elaiophylin promotes autophagosome accumulation but blocks autophagic flux by attenuating lysosomal cathepsin activity, resulting in the accumulation of SQSTM1/p62 in various human ovarian cancer cell lines [13]; (3) Oblongifolin C (OC), a natural small molecule compound extracted from Garcinia yunnanensis $\mathrm{Hu}$, is a potent autophagic flux inhibitor. Exposure to OC results 
in an increased number of autophagosomes and impaired degradation of SQSTM1/p62 [14]; (4) p53 siRNA and epigallocatechin gallate (EGCG) dual therapy leads to the activation of pro-apoptotic genes, the inhibition of pro-survival autophagy and cell network formation [15]; (5) Frondoside A, a triterpenoid saponin with a sugar-steroid structure, is derived from the orange-footed sea cucumber, Cucumaria frondosa and inhibits pro-survival autophagy, a known mechanism of drug resistance in the human urothelial carcinoma cell lines and showed the synergistic activity with cisplatin and gemcitabine [16]; and (6) Rhizochalinin (Rhiz) from the marine sponge Rhizochalina incrustata, a novel sphingolipid-like marine compound is characterized by a unique combination of anti-cancer properties via one scenario of pro-survival autophagy inhibition in the human prostate cancer cells [17]. Thereby, natural products have also been demonstrated as autophagy inducers.

\subsection{Natural Autophagy Inducers from Herbs}

Conversely, the autophagy cascade may play a regulatory or major role resulting in cell death, particularly when natural products are employed. Apparently, more recent studies have elicited the benefits and molecular mechanisms triggered by natural active components for anti-cancer activity, particularly in the induction of autophagy. Sirolimus, also known as rapamycin, is isolated from the bacterium Streptomyces hygroscopicus, and may be the most famous natural autophagy inducer in autophagy research [18]. The extract of Emblica officinalis (Amla) inhibits ovarian cancer (OC) cell growth in vitro and in vivo, possibly via inhibition of angiogenesis and activation of autophagy in OC [19]. The natural compound lipoic acid (LA) inhibits O (6)-methylguanine-DNA methyltransferase (MGMT) and induces autophagy and subsequently LA enhances the cytotoxic effects of temozolomide in HCT-116 cells [20]. The combination of gossypol and BRD4770 increased LC3-II levels and the autophagosome number in PANC-1 cells. The compound combination appears to act in a BNIP3 (B-cell lymphoma $219-\mathrm{kDa}$ interacting protein)-dependent manner, suggesting that these compounds act together to induce autophagy-related cell death in pancreatic cancer cells [21]. The synthesized natural alkaloid berberine derivatives are able to induce autophagy for human colon carcinoma HCT-116 and SW613-B3 cell lines [22]. C-1 acetoxymethyl-a derivative of 7-deoxypancratistatin-and JC-TH-acetate-4 (JCTH-4) are novel compounds capable of selectively inducing apoptosis and autophagy in human colorectal cancer (CRC) cells alone and in combination with tamoxifen (TAM) [23]. Honokiol (HNK), a biphenolic natural compound, significantly inhibits melanoma cell proliferation, viability, clonogenicity, and induces autophagy on melanoma cells [24]. Isobavachalcone (IBC), a natural chalcone compound, induces apoptosis- and autophagy-related cell death in myeloma cells [25]. In numerous breast cancer studies, MCF-7 is frequently used as a cell model for testing the efficacy of anti-cancer agents. Several natural compounds have been shown to be autophagy inducers, such as rottlerin [26], chrysin-organotin based on chrysin [27], betanin/isobetanin from beetroots [28], cucurbitacin B from cucurbitaceous plants [29], and 2-ethyl-3-O-sulphamoyl-estra-1,3,5(10)16-tetraene, a 17- $\beta$-estradiol analogue [30]. Additionally, the functions of rottlerin in caspase-3-deficient MCF-7 and caspases-3-transfected MCF-7 are significantly different. In caspase-3-deficient MCF-7, rottlerin acts as an autophagy inducer, while rottlerin acts as an apoptotic activator in caspases-3-transfected MCF-7 [26]. Furthermore, chrysin-organotin [27] and cucurbitacin B [29]. Recently, pancratistatin (PST) analogue, a C-1 acetoxymethyl derivative of 7-deoxypancratistatin (JCTH-4) induced apoptosis and autophagy, and accelerates cell death with combinatorial treatment using time-lapse microscopy in human breast adenocarcinoma and neuroblastoma cells with tamoxifen [31]. Table 1 summarizes our collection of compound names, herb sources, and cancer types to address natural autophagic inducers for anti-cancer activity. 
Table 1. Natural autophagic inducers from compound names and herb sources evaluated for various types of cancer.

\begin{tabular}{cccc}
\hline Compounds & Sources & Cancer Type & Reference \\
\hline Rdipusilloside I & Ardisia pusilla A. DC & Glioblastoma multiforme & {$[32]$} \\
\hline Gossypol & Cotton & Glioblastoma multiforme & {$[33]$} \\
\cline { 2 - 4 } & & Breast cancer & {$[21]$} \\
\hline Monanchocidin A & Monanchora pulchra & $\begin{array}{c}\text { Genitourinary } \\
\text { malignancies }\end{array}$ & {$[34]$} \\
\hline Zerumbone & Zingiber zerumbet Smith & Prostate cancer & {$[35]$} \\
\hline Ery5 & Magnolol & Prostate cancer & {$[36]$} \\
\hline Cotylenin A + phenethyl isothiocyanate & Garcinia yunnanensis Hu & Pancreatic cancer & {$[37]$} \\
\hline Oblongifolin C & & Cholangiocarcinoma & {$[38]$} \\
\hline Spicatoside A & Liriope platyphylla & Colorectal cancer & {$[39]$} \\
\hline Compound 4h & Colchicum autumnale & Colorectal cancer & {$[40]$} \\
\hline Dimethyl cardamonin & $\begin{array}{c}\text { Syzygium samarangense (Blume) Merr. } \\
\text { \& L.M. Perry (Myrtaceae) }\end{array}$ & Colorectal cancer & {$[41]$} \\
\hline JCTH-4 & pancratistatin & Colorectal cancer & {$[23]$} \\
\hline Isocryptotanshinone & Salvia miltiorrhiza & Lung cancer & {$[42]$} \\
\hline Honokiol & Magnolia officinalis & Melanoma & {$[24]$} \\
\hline Isobavachalcone & Psoralea corylifolia & Myeloma & {$[25]$} \\
\hline Celastrol & Tripterygium wilfordii & Cervical cancer & {$[43]$} \\
\hline Goniothalamin & Goniothalamus macrophyllus (Blume) & Renal cancer & {$[44]$} \\
\hline Hook. f. \& Thomson var. macrophyllus & The & \\
\hline
\end{tabular}

\section{Underlying Mechanisms of Natural Compound-Induced Autophagy}

Accordingly, the mechanisms of natural product actions including plant-derived anti-cancer drug-induced apoptotic cell death may be intrinsic or extrinsic; p53-dependent or -independent pathways; and caspase-dependent or -independent manner in cancer research. Alternative modes of non-apoptotic cell death by plant-derived anti-cancer drugs are emerging, and mainly comprise autophagy, necrosis-like programmed cell death, mitotic catastrophe, and senescence leading to cell death. Considering that non-apoptotic cell death mechanisms of plant-derived anticancer drugs are less reviewed than the apoptotic ones, this article attempts to focus on such alternative cell death pathways for some representative anti-cancer plant-based compounds in clinical development. The understanding of autophagy-induced mechanisms of natural products could afford deep insight into the possibility of exploiting novel molecular pathways and targets of plant-derived compounds for future cancer therapeutics [45]. Various targets or molecules, including sequestosome-1 (SQSTM1), also known as p62, mammalian target of rapamycin (mTOR), uncoordinated-51-like kinase 1 (ULK1), and autophagy-related protein 12 (Atg12), are commonly applied in observations of autophagy, and the Akt/mTOR/p70 ribosomal protein S6 kinase (p70S6K) and the extracellular signal-regulated kinases $1 / 2$ (ERK1/2) pathways are two major pathways that regulate autophagy induced by nutrient starvation $[11,46]$. In autophagy, rapamycin specifically targets mTOR and further inhibits the activity of mTOR. The inhibition of mTOR subsequently activates Beclin-1 and down-regulates PI3K-ClassIII to finally induce autophagy [47]. In addition to mTOR inhibition, sirolimus (rapamycin) also regulates microRNA expression, which is involved in tumor growth and drug resistance, including miR-7a, miR-17-92, miR-99a, and miR-100 [48]. Some reports have focused on the inhibitory effect of specific cancer cell types and an understanding of mechanical actions in addition to the abovementioned signal pathways, while several other potential signal pathways have been explored (Table 2). On the other hand, we also highlighted three exemplified natural compounds such as curcumin, 16-hydroxycleroda-3,13-dien-15,16-olide, and prodigiosin as interesting autophagy inducers to discuss more facets in the following section. 
Table 2. Natural autophagy inducers and their effect on signal transduction pathways.

\begin{tabular}{|c|c|c|c|}
\hline Pathways & Compounds & Cancer Type & Reference \\
\hline Akt & (+)-Grandifloracin & Pancreatic Carcinoma & [49] \\
\hline \multirow{2}{*}{ PI3K/Akt } & Magnolol & Gastric Adenocarcinoma & [50] \\
\hline & Apigenin & Leukemia & [51] \\
\hline PI3K/Akt/HK2 & Neoalbaconol & Nasopharynx cancer & [52] \\
\hline \multirow{4}{*}{ Akt/mTOR } & Salvianolic Acid B & Colorectal cancer & [53] \\
\hline & Guttiferone K & Uterus Carcinoma & [54] \\
\hline & Resveratrol & Melanoma & [55] \\
\hline & Honokiol & Melanoma & [56] \\
\hline Akt/mTOR/p70S6K & Curcumin & Glioma & [57] \\
\hline TR3/Akt2 & 1-(3,4,5-Trihydroxyphenyl) nonan-1-one & Melanoma & [58] \\
\hline \multirow{2}{*}{ AMPK } & (2R)-kazinol B + Bafilomycin A1 & Hepatocarcinoma & [59] \\
\hline & Oridonin & Colorectal cancer & [60] \\
\hline \multirow{3}{*}{ AMPK/mTOR } & Kazinol A & Bladder cancer & [61] \\
\hline & Cryptotanshinone & Hepatocarcinoma & [62] \\
\hline & Tanshinone IIA & Leukemia & [63] \\
\hline \multirow{2}{*}{ CaMKK/AMPK/mTOR } & \multirow{2}{*}{ Alisol B } & Nasopharynx cancer & \\
\hline & & Prostate cancer & \\
\hline \multirow{4}{*}{ Beclin 1} & Bromelain $+\mathrm{N}$-acetylcysteine & Gastric Adenocarcinoma & {$[64,65]$} \\
\hline & Paratocarpin E & Breast cancer & [66] \\
\hline & Evodiamine & Gastric Adenocarcinoma & [67] \\
\hline & Alma extract & Ovarian cancer & [19] \\
\hline \multirow{5}{*}{ ERK1/2 } & Curcumin & $\begin{array}{l}\text { Uterine cancer } \\
\text { Leiomyosarcoma }\end{array}$ & [68] \\
\hline & Curcumin & Glioma & [57] \\
\hline & \multirow{3}{*}{ Sarsaparilla extract } & Gastric Adenocarcinoma & [69] \\
\hline & & Breast cancer & \\
\hline & & Colorectal cancer & \\
\hline p38/ERK1/2 & Resveratrol & Glioma & [70] \\
\hline $\mathrm{p} 38 / \mathrm{JNK}$ & Compound 1 from Adenophora triphylla var. japonica & Gastric Adenocarcinoma & [71] \\
\hline Raf/ERK/p90RSK & Tanshinone IIA & Leukemia & [63] \\
\hline miR-25/ULK1 & Isoliquiritigenin & Breast cancer & [72] \\
\hline NF- $k B$ & Helenalin & Ovarian cancer & [73] \\
\hline p53 & Capsaicin & Lung cancer & [74] \\
\hline p62 & Zosteropenillines 7 & Prostate cancer & [75] \\
\hline p62/LC3-II & Oridonin + NVP-BEZ235 & Neuroblastoma & [76] \\
\hline LC3-II/Atg5/Beclin-1 & Resveratrol & Glioblastoma multiforme & [77] \\
\hline LC3/Atg7/Atg12 & Salvigenin & Neuroblastoma & [78] \\
\hline p-eIF2 $\alpha$ & Trehalose & Neuroblastoma & [79] \\
\hline PERK/eIF2 $\alpha$ & Benzyl isothiocyanate & Lung cancer & [80] \\
\hline ROS & Gelomulide K & Breast cancer & [81] \\
\hline \multirow{3}{*}{ ROS/JNK } & Juglanin & Breast cancer & [82] \\
\hline & Ginsenoside K & Colorectal cancer & [83] \\
\hline & Ursolic acid & Colorectal cancer & [84] \\
\hline ROS/MEK/ERK & CYT-Rx20 & Breast cancer & [85] \\
\hline Wnt/ $\beta$-catenin & Resveratrol & Breast cancer & [86] \\
\hline HSF1/Hsp70/ubiquintin & Oridonin & Leukemia & [87] \\
\hline RelB/p52 & Baicalin & Hepatocarcinoma & [88] \\
\hline
\end{tabular}

AMP-activated protein kinase (AMPK); Calcium/calmodulin-dependent protein kinase kinase (CaMKK); c-Jun N-terminal kinases (JNK); Eukaryotic translation initiation factor 2 subunit 1 (eIF2 $\alpha$ ); Extracellular signal-regulated kinases (ERK); Heat shock factor 1 (HSF1); Heat shock protein 70 (Hsp70); Hexokinase 2 (HK2); Mammalian target of rapamycin (mTOR); Microtubule-associated protein 1 light chain $3 \alpha$ (LC3); Mitogen-activated protein kinase kinase (MEK); Nerve growth factor IB (TR3); Nuclear factor k-light-chain-enhancer of activated B cells (NF-kB); p70 ribosomal protein S6 kinase $\beta-1$ (p70S6K); Phosphoinositide 3-kinase (PI3K); Protein kinase B (Akt, PKB); Protein kinase RNA-like endoplasmic reticulum kinase (PERK); Reactive oxygen species (ROS); Sequestosome-1 (SQSTM1); Uncoordinated-51-like kinase (ULK); Wingless/Integrated (Wnt). 


\subsection{Curcumin}

Curcumin is a yellow pigment isolated from turmeric (Curcuma longa L.). Recent study has shown that curcumin provides numerous biological activities including anti-oxidation, antiprotozoal, antimicrobial, immunomodulation, anti-angiogenesis, and antitumor, among others [89]. On anti-tumor activity, curcumin regulates metastasis-relating protein MMP-9 for reducing tumor metastasis [90]. Moreover, curcumin induces $\mathrm{G}_{2} / \mathrm{M}$ phase arresting in glioma cell via upregulation of p21 and ING4, and further induces apoptosis through up-regulating BAX and down-regulating the $\mathrm{Bcl}-2$ and NF- $\mathrm{KB}$ signaling pathway in glioma cells [91]. In autophagy, curcumin induces autophagy via the ERK1/2 signaling pathway (Table 2). In glioblastoma, curcumin induces autophagy in vitro and in vivo, and is less toxic to normal cells, especially in glioma-initiating cells (GICs) [92]. A curcumin derivative-2E,6E-2-(1H-indol-3-yl)methylene)-6-(4-hydroxy-3-methoxybenzylidene)-cyclohexanone (IHCH) - inhibited A549 cell growth and induced the formation of characteristic autophago-lysosomes in a dose- and time-dependent manner [93].

\subsection{6-Hydroxycleroda-3,13-dien-15,16-olide (HCD)}

Polyalthia longifolia var. pendula Linn is popularly known as ulta Ashok in India and is widely grown in gardens in tropical and subtropical Asia, such as the southern part of Taiwan, Pakistan, and Sri Lanka, as an evergreen ornamental tree. Many parts of $P$. longifolia var. pendula Linn tree are important in traditional Indian medicine [94], and encompass various biological functions, such as anti-inflammatory activity in neutrophils, cytotoxicity towards breast cancer cells, and hepatoma cancer cells [95]. The bark has shown to have medicinal value in the treatment of skin diseases, fever, hypertension, diabetes, and helminthiasis [96]. Recently, the chemical components of P. longifolia var. pendula such as diterpenes (clerodane and triterpenes) and aporphine alkaloids have been isolated. Diterpenoids in the hexane extract of $P$. longifolia seeds has exhibited significant anti-bacterial and anti-fungal activity [97]. Clerodane diterpenes can induce apoptosis in human leukemia HL-60 cells [98]. Moreover, 16-Hydroxycleroda-3,13-dien-15,16-olide (HCD) and its analogs extracted from the bark of $P$. longifolia have strong anti-inflammatory activity [99]. The enhanced expression of cyto-protective HO-1 factor and anti-inflammatory enzyme in microglia has been reported [100]. Hereby, the induction of apoptosis in leukemia K562 cells via a reduction in histone-modifying enzymes, PRC2-mediated gene silencing, the reactivation of downstream tumor suppressor gene expressions [101], via the PI3K/Akt pathway, and Aurora B resulting in gene silencing and cell cycle disturbance [102]. Our previous studies have demonstrated that HCD could cause apoptosis of two brain cancer cell lines, N18 and C6, via inhibition of focal adhesion kinase (FAK)-related signaling pathway and accordingly induced the autophagic cell death through ROS generation and p38/ERK1/2 signaling pathway activation $[103,104]$. In oral squamous cell carcinoma, HCD induced autophagy by activating AMPK $\alpha$ and inhibiting Akt, PI3K-ClassIII, and Beclin-1 activity [105].

\subsection{Prodigiosin (PG)}

Prodigiosin (PG, PubChem CID: 5377753) is an alkaloid and natural red pigment, which is a secondary metabolite of Serratia marcescens and also from actinomycete bacteria [106]. It is characterized by a common pyrrolyl pyrromethene skeleton $[107,108]$. The biological role of these pigments in the producer organisms remains unclear. Bacterial PGs and their synthetic derivatives have antimicrobial (bactericidal and bacteriostatic) [109-112], antimalarial [109,110,113], and antitumor [109,110,114-116] activities. In addition, they have been shown to be effective apoptotic agents against various cancer cell lines [117], with multiple cellular targets including multi-drug resistant cells with little or no toxicity towards normal cell lines and induce apoptosis in T and B lymphocytes $[118,119]$. Recently, PG can induce apoptosis in various cancer cells with low toxicity on normal cells and PG-induced apoptosis may ascribe to Bcl-2 and survivin inhibition in colorectal cancer HT-29 cells [120]. Moreover, PG and its structural analogue (compound R) have induced the expression of p53 target genes accompanied by 
cell-cycle arrest and apoptosis in p53-deficient cancer cells [121]. A previous study has indicated that PG could be effective as a potential inhibitor compound against COX-2 protein, and can be applied as an anti-inflammatory drug [122]. In melanoma cells, PG activates the mitochondrial apoptotic pathway by disrupting an anti-apoptotic member of the BCL-2 family-MCL-1/BAK complexes by binding to the BH3 domain [123]. Additionally, PG exerts nearly identical cytotoxic effects on the resistant cells in comparison to their parental lines to reveal that this pro-apoptotic agent acts independently on the overexpression of multi-drug resistance transporters-MDR1, BCRP, or MRP [124]. Mechanistically, PG engages the IRE1-JNK and PERK-eIF2 $\alpha$ branches of the unfolded protein response (UPR) signaling to up-regulate $\mathrm{CHOP}$ that, in turn, mediates BCL2 suppression to induce cell death in multiple human breast carcinoma cell lines [125].

\section{Perspectives: Natural Autophagy Inducers Potentiate a New Era of Chemotherapeutic Drug Discovery}

This review is valuable in terms of clarifying important directions for research on the major role of autophagy inducers resulting in cell death and the underlying mechanisms as seen with numerous natural products. Notably, natural products are an important resource in the discovery of lead compound for anti-cancer drug development, and study on the role of autophagy in the tumor suppressive effects of natural products continues to produce insights into and emerging from difficulties. It is noteworthy that technical variations in detecting autophagy might affect data quality, and study should focus on elaborating the role of natural inducers in deciding cell fate. In vivo study monitoring of natural autophagy inducers in cancer treatment is expected to be a critical effort for the future. Furthermore, the clinically relevant action of autophagy-inducing natural products should be emphasized in translational study.

Author Contributions: Yaw-Syan Fu, May-Jywan Tsai, Henrich Cheng, and Ching-Feng Weng contributed to the literature collection, review and present idea; Shian-Ren Lin and Ching-Feng Weng wrote the paper; all authors have read and approved this manuscript.

Conflicts of Interest: The authors declare no conflict of interest.

$\begin{array}{ll}\text { Abbreviations } \\ \text { 3-MA } & \text { 3-Methyladenine } \\ \text { 5-FU } & \text { 5-Fluorouracil } \\ \text { HCD } & \text { 16-Hydroxycleroda-3,13-dien-15,16-olide } \\ \text { AMPK } & \text { AMP-activated protein kinase } \\ \text { CaMKK } & \text { Calcium/calmodulin-dependent protein kinase kinase } \\ \text { JNK } & \text { c-Jun N-terminal kinases } \\ \text { eIF2 } \alpha & \text { Eukaryotic translation initiation factor 2 subunit } 1 \\ \text { EGCG } & \text { Epigallocatechin gallate } \\ \text { ERK } & \text { Extracellular signal-regulated kinases } \\ \text { GICs } & \text { Glioma-initiating cells } \\ \text { HSF1 } & \text { Heat shock factor 1 } \\ \text { Hsp70 } & \text { Heat shock protein 70 } \\ \text { HK2 } & \text { Hexokinase 2 } \\ \text { HNK } & \text { Honokiol } \\ \text { CRC } & \text { Human colorectal cancer } \\ \text { IBC } & \text { Isobavachalcone } \\ \text { mTOR } & \text { Mammalian target of rapamycin } \\ \text { LC3 } & \text { Microtubule-associated protein 1 light chain } 3 \alpha \\ \text { MEK } & \text { Mitogen-activated protein kinase kinase } \\ \text { MGMT } & \text { O (6)-methylguanine-DNA methyltransferase } \\ & \end{array}$




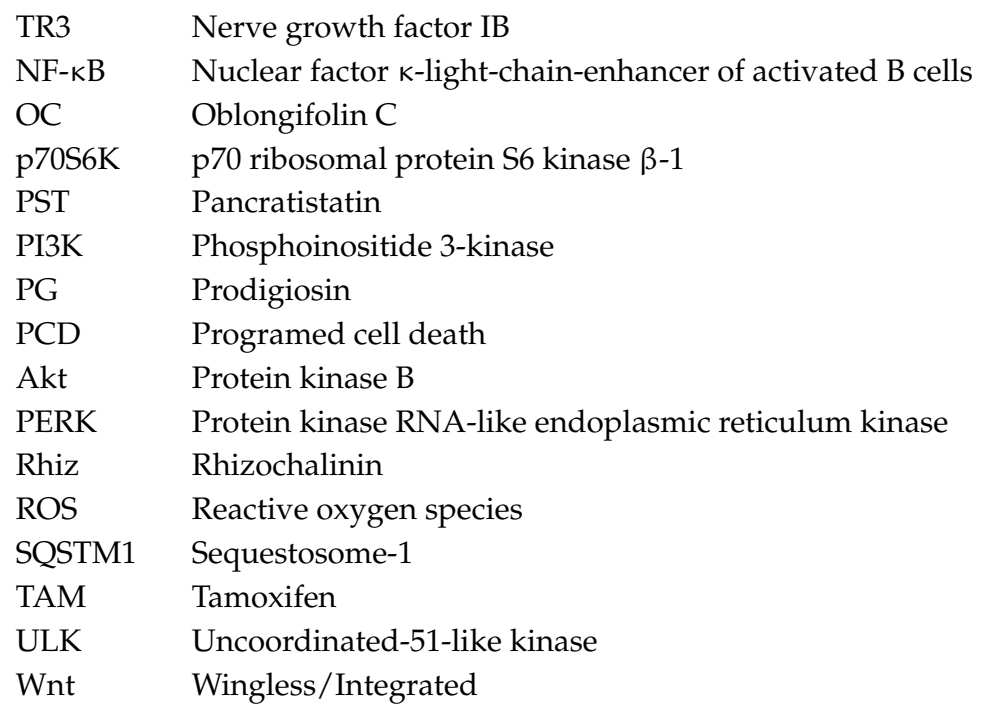

\section{References}

1. Bast, R.C. Cardinal manifestations of cancer. In Holland-Frei Cancer Medicine, 9th ed.; Holland, J.F., Hong, W.K., Kufe, D.W., Bast, R.C., Jr., Hait, W.N., Pollock, R.E., Weichselbaum, R.R., Eds.; John Wiley \& Sons, Inc.: Hoboken, NJ, USA, 2016; pp. 3-7.

2. Disease, G.B.D.; Injury, I.; Prevalence, C. Global, regional, and national incidence, prevalence, and years lived with disability for 310 diseases and injuries, 1990-2015: A systematic analysis for the global burden of disease study 2015. Lancet 2016, 388, 1545-1602.

3. Stewart, B.W.; Wild, C. World Cancer Report 2014; International Agency for Research on Cancer, WHO Press: Lyon, France; Geneva, Switzerland, 2014.

4. Feigin, V.; GBD 2015 Mortality; Causes of Death Collaborators. Global, regional, and national life expectancy, all-cause mortality, and cause-specific mortality for 249 causes of death, 1980-2015: A systematic analysis for the global burden of disease study 2015. Lancet 2016, 388, 1459-1544.

5. Von Hoff, D.D.; Hanauske, A.R. Preclinical and early clinical development of chemotherapeutic drugs, mechanism-based agents and biologics. In Holland-Frei Cancer Medicine, 8th ed.; Hong, K.W., Kufe, D.W., Bast, R.C., Jr., Hait, W., Pollock, R.E., Weichselbaum, R.R., Holland, J.F., Frei, E., III, Eds.; People's Medical Publishing House-USA: Shelton, CT, USA, 2010; pp. 568-587.

6. Barry, M.A.; Behnke, C.A.; Eastman, A. Activation of programmed cell death (apoptosis) by cisplatin, other anticancer drugs, toxins and hyperthermia. Biochem. Pharmacol. 1990, 40, 2353-2362. [CrossRef]

7. Tacar, O.; Sriamornsak, P.; Dass, C.R. Doxorubicin: An update on anticancer molecular action, toxicity and novel drug delivery systems. J. Pharm. Pharmacol. 2013, 65, 157-170. [CrossRef] [PubMed]

8. Mizushima, N. Autophagy: Process and function. Genes Dev. 2007, 21, 2861-2873. [CrossRef] [PubMed]

9. Mizushima, N.; Levine, B.; Cuervo, A.M.; Klionsky, D.J. Autophagy fights disease through cellular self-digestion. Nature 2008, 451, 1069-1075. [CrossRef] [PubMed]

10. Choi, K.S. Autophagy and cancer. Exp. Mol. Med. 2012, 44, 109-120. [CrossRef] [PubMed]

11. Klionsky, D.J.; Abdelmohsen, K.; Abe, A.; Abedin, M.J.; Abeliovich, H.; Acevedo Arozena, A.; Adachi, H.; Adams, C.M.; Adams, P.D.; Adeli, K.; et al. Guidelines for the use and interpretation of assays for monitoring autophagy, 3rd ed. Autophagy 2016, 12, 1-222. [CrossRef] [PubMed]

12. Wang, Z.; Zhang, J.; Wang, Y.; Xing, R.; Yi, C.; Zhu, H.; Chen, X.; Guo, J.; Guo, W.; Li, W.; et al. Matrine, a novel autophagy inhibitor, blocks trafficking and the proteolytic activation of lysosomal proteases. Carcinogenesis 2013, 34, 128-138. [CrossRef] [PubMed]

13. Zhao, X.; Fang, Y.; Yang, Y.; Qin, Y.; Wu, P.; Wang, T.; Lai, H.; Meng, L.; Wang, D.; Zheng, Z.; et al. Elaiophylin, a novel autophagy inhibitor, exerts antitumor activity as a single agent in ovarian cancer cells. Autophagy 2015, 11, 1849-1863. [CrossRef] [PubMed] 
14. Lao, Y.; Wan, G.; Liu, Z.; Wang, X.; Ruan, P.; Xu, W.; Xu, D.; Xie, W.; Zhang, Y.; Xu, H.; et al. The natural compound oblongifolin $C$ inhibits autophagic flux and enhances antitumor efficacy of nutrient deprivation. Autophagy 2014, 10, 736-749. [CrossRef] [PubMed]

15. Braicu, C.; Pileczki, V.; Pop, L.; Petric, R.C.; Chira, S.; Pointiere, E.; Achimas-Cadariu, P.; Berindan-Neagoe, I. Dual targeted therapy with p53 siRNA and epigallocatechingallate in a triple negative breast cancer cell model. PLoS ONE 2015, 10, e0120936. [CrossRef] [PubMed]

16. Dyshlovoy, S.A.; Madanchi, R.; Hauschild, J.; Otte, K.; Alsdorf, W.H.; Schumacher, U.; Kalinin, V.I.; Silchenko, A.S.; Avilov, S.A.; Honecker, F.; et al. The marine triterpene glycoside frondoside A induces p53-independent apoptosis and inhibits autophagy in urothelial carcinoma cells. BMC Cancer 2017, 17, 93-103. [CrossRef] [PubMed]

17. Dyshlovoy, S.A.; Otte, K.; Alsdorf, W.H.; Hauschild, J.; Lange, T.; Venz, S.; Bauer, C.K.; Bahring, R.; Amann, K.; Mandanchi, R.; et al. Marine compound rhizochalinin shows high in vitro and in vivo efficacy in castration resistant prostate cancer. Oncotarget 2016, 7, 69703-69717. [CrossRef] [PubMed]

18. Vezina, C.; Kudelski, A.; Sehgal, S.N. Rapamycin (AY-22, 989), a new antifungal antibiotic. I. Taxonomy of the producing streptomycete and isolation of the active principle. J. Antibiot (Tokyo) 1975, 28, 721-726. [CrossRef] [PubMed]

19. De, A.; De, A.; Papasian, C.; Hentges, S.; Banerjee, S.; Haque, I.; Banerjee, S.K. Emblica officinalis extract induces autophagy and inhibits human ovarian cancer cell proliferation, angiogenesis, growth of mouse xenograft tumors. PLoS ONE 2013, 8, e72748. [CrossRef] [PubMed]

20. Goder, A.; Nagel, G.; Kraus, A.; Dorsam, B.; Seiwert, N.; Kaina, B.; Fahrer, J. Lipoic acid inhibits the DNA repair protein $\mathrm{O}^{6}$-methylguanine-DNA methyltransferase (MGMT) and triggers its depletion in colorectal cancer cells with concomitant autophagy induction. Carcinogenesis 2015, 36, 817-831. [CrossRef] [PubMed]

21. Yuan, Y.; Tang, A.J.; Castoreno, A.B.; Kuo, S.Y.; Wang, Q.; Kuballa, P.; Xavier, R.; Shamji, A.F.; Schreiber, S.L.; Wagner, B.K. Gossypol and an HMT G9a inhibitor act in synergy to induce cell death in pancreatic cancer cells. Cell Death Dis. 2013, 4, e690. [CrossRef] [PubMed]

22. Guaman Ortiz, L.M.; Croce, A.L.; Aredia, F.; Sapienza, S.; Fiorillo, G.; Syeda, T.M.; Buzzetti, F.; Lombardi, P.; Scovassi, A.I. Effect of new berberine derivatives on colon cancer cells. Acta Biochim. Biophys. Sin. (Shanghai) 2015, 47, 824-833. [CrossRef] [PubMed]

23. Ma, D.; Tremblay, P.; Mahngar, K.; Akbari-Asl, P.; Collins, J.; Hudlicky, T.; McNulty, J.; Pandey, S. A novel synthetic C-1 analogue of 7-deoxypancratistatin induces apoptosis in p53 positive and negative human colorectal cancer cells by targeting the mitochondria: Enhancement of activity by tamoxifen. Investig. New Drugs 2012, 30, 1012-1027. [CrossRef] [PubMed]

24. Kaushik, G.; Venugopal, A.; Ramamoorthy, P.; Standing, D.; Subramaniam, D.; Umar, S.; Jensen, R.A.; Anant, S.; Mammen, J.M. Honokiol inhibits melanoma stem cells by targeting notch signaling. Mol. Carcinog. 2015, 54, 1710-1721. [CrossRef] [PubMed]

25. Zhao, S.; Ma, C.M.; Liu, C.X.; Wei, W.; Sun, Y.; Yan, H.; Wu, Y.L. Autophagy inhibition enhances isobavachalcone-induced cell death in multiple myeloma cells. Int. J. Mol. Med. 2012, 30, 939-944. [PubMed]

26. Torricelli, C.; Salvadori, S.; Valacchi, G.; Soucek, K.; Slabáková, E.; Muscettola, M.; Volpi, N.; Maioli, E. Alternative pathways of cancer cell death by rottlerin: Apoptosis versus autophagy. Evid. Based Complement Alternat. Med. 2012, 2012, 11. [CrossRef] [PubMed]

27. Xuan, H.Z.; Zhang, J.H.; Wang, Y.H.; Fu, C.L.; Zhang, W. Anti-tumor activity evaluation of novel chrysin-organotin compound in MCF-7 cells. Bioorg. Med. Chem. Lett. 2016, 26, 570-574. [CrossRef] [PubMed]

28. Nowacki, L.; Vigneron, P.; Rotellini, L.; Cazzola, H.; Merlier, F.; Prost, E.; Ralanairina, R.; Gadonna, J.P.; Rossi, C.; Vayssade, M. Betanin-enriched red beetroot (Beta vulgaris L.) extract induces apoptosis and autophagic cell death in MCF-7 cells. Phytother. Res. 2015, 29, 1964-1973. [CrossRef] [PubMed]

29. Ren, G.; Sha, T.; Guo, J.; Li, W.; Lu, J.; Chen, X. Cucurbitacin B induces DNA damage and autophagy mediated by reactive oxygen species (ROS) in MCF-7 breast cancer cells. J. Nat. Med. 2015, 69, 522-530. [CrossRef] [PubMed]

30. Nkandeu, D.S.; Mqoco, T.V.; Visagie, M.H.; Stander, B.A.; Wolmarans, E.; Cronje, M.J.; Joubert, A.M. In vitro changes in mitochondrial potential, aggresome formation and caspase activity by a novel 17- $\beta$-estradiol analogue in breast adenocarcinoma cells. Cell Biochem. Funct. 2013, 31, 566-574. [PubMed] 
31. Ma, D.; Collins, J.; Hudlicky, T.; Pandey, S. Enhancement of apoptotic and autophagic induction by a novel synthetic C-1 analogue of 7-deoxypancratistatin in human breast adenocarcinoma and neuroblastoma cells with tamoxifen. J. Vis. Exp. 2012, 63. [CrossRef] [PubMed]

32. Wang, R.; Xiao, X.; Wang, P.Y.; Wang, L.; Guan, Q.; Du, C.; Wang, X.J. Stimulation of autophagic activity in human glioma cells by anti-proliferative ardipusilloside I isolated from Ardisia pusilla. Life Sci. 2014, 110, 15-22. [CrossRef] [PubMed]

33. Keshmiri-Neghab, H.; Goliaei, B.; Nikoofar, A. Gossypol enhances radiation induced autophagy in glioblastoma multiforme. Gen. Physiol. Biophys. 2014, 33, 433-442. [CrossRef] [PubMed]

34. Dyshlovoy, S.A.; Hauschild, J.; Amann, K.; Tabakmakher, K.M.; Venz, S.; Walther, R.; Guzii, A.G.; Makarieva, T.N.; Shubina, L.K.; Fedorov, S.N.; et al. Marine alkaloid monanchocidin a overcomes drug resistance by induction of autophagy and lysosomal membrane permeabilization. Oncotarget 2015, 6, 17328-17341. [CrossRef] [PubMed]

35. Chan, M.L.; Liang, J.W.; Hsu, L.C.; Chang, W.L.; Lee, S.S.; Guh, J.H. Zerumbone, a ginger sesquiterpene, induces apoptosis and autophagy in human hormone-refractory prostate cancers through tubulin binding and crosstalk between endoplasmic reticulum stress and mitochondrial insult. Naunyn Schmiedebergs Arch. Pharmacol. 2015, 388, 1223-1236. [CrossRef] [PubMed]

36. Kumar, S.; Guru, S.K.; Pathania, A.S.; Kumar, A.; Bhushan, S.; Malik, F. Autophagy triggered by magnolol derivative negatively regulates angiogenesis. Cell Death Dis. 2013, 4, e889. [CrossRef] [PubMed]

37. Kasukabe, T.; Honma, Y.; Okabe-Kado, J.; Higuchi, Y.; Kato, N.; Kumakura, S. Combined treatment with cotylenin A and phenethyl isothiocyanate induces strong antitumor activity mainly through the induction of ferroptotic cell death in human pancreatic cancer cells. Oncol. Rep. 2016, 36, 968-976. [PubMed]

38. Zhang, A.; He, W.; Shi, H.; Huang, X.; Ji, G. Natural compound oblongifolin C inhibits autophagic flux, and induces apoptosis and mitochondrial dysfunction in human cholangiocarcinoma QBC939 cells. Mol. Med. Rep. 2016, 14, 3179-3183. [CrossRef] [PubMed]

39. Kim, W.K.; Pyee, Y.; Chung, H.J.; Park, H.J.; Hong, J.Y.; Son, K.H.; Lee, S.K. Antitumor activity of spicatoside A by modulation of autophagy and apoptosis in human colorectal cancer cells. J. Nat. Prod. 2016, 79, 1097-1104. [CrossRef] [PubMed]

40. Kumar, A.; Singh, B.; Sharma, P.R.; Bharate, S.B.; Saxena, A.K.; Mondhe, D.M. A novel microtubule depolymerizing colchicine analogue triggers apoptosis and autophagy in HCT-116 colon cancer cells. Cell Biochem. Funct. 2016, 34, 69-81. [CrossRef] [PubMed]

41. Ko, H.; Kim, Y.J.; Amor, E.C.; Lee, J.W.; Kim, H.C.; Kim, H.J.; Yang, H.O. Induction of autophagy by dimethyl cardamonin is associated with proliferative arrest in human colorectal carcinoma HCT116 and LOVO cells. J. Cell. Biochem. 2011, 112, 2471-2479. [CrossRef] [PubMed]

42. Guo, S.; Luo, W.; Liu, L.; Pang, X.; Zhu, H.; Liu, A.; Lu, J.; Ma, D.L.; Leung, C.H.; Wang, Y.; et al. Isocryptotanshinone, a STAT3 inhibitor, induces apoptosis and pro-death autophagy in A549 lung cancer cells. J. Drug Target 2016, 24, 934-942. [CrossRef] [PubMed]

43. Wang, W.B.; Feng, L.X.; Yue, Q.X.; Wu, W.Y.; Guan, S.H.; Jiang, B.H.; Yang, M.; Liu, X.; Guo, D.A. Paraptosis accompanied by autophagy and apoptosis was induced by celastrol, a natural compound with influence on proteasome, ER stress and Hsp90. J. Cell. Physiol. 2012, 227, 2196-2206. [CrossRef] [PubMed]

44. De Fatima, A.; Zambuzzi, W.F.; Modolo, L.V.; Tarsitano, C.A.; Gadelha, F.R.; Hyslop, S.; de Carvalho, J.E.; Salgado, I.; Ferreira, C.V.; Pilli, R.A. Cytotoxicity of goniothalamin enantiomers in renal cancer cells: Involvement of nitric oxide, apoptosis and autophagy. Chem. Biol. Interact. 2008, 176, 143-150. [CrossRef] [PubMed]

45. Chen, N.; Karantza, V. Autophagy as a therapeutic target in cancer. Cancer Biol. Ther. 2011, 11, 157-168. [CrossRef] [PubMed]

46. Glick, D.; Barth, S.; Macleod, K.F. Autophagy: Cellular and molecular mechanisms. J. Pathol. 2010, $221,3-12$. [CrossRef] [PubMed]

47. Choi, A.M.; Ryter, S.W.; Levine, B. Autophagy in human health and disease. N. Engl. J. Med. 2013, 368, 651-662. [CrossRef] [PubMed]

48. Granata, S.; Dalla Gassa, A.; Carraro, A.; Brunelli, M.; Stallone, G.; Lupo, A.; Zaza, G. Sirolimus and everolimus pathway: Reviewing candidate genes influencing their intracellular effects. Int. J. Mol. Sci. 2016, 17, 735. [CrossRef] [PubMed] 
49. Ueda, J.Y.; Athikomkulchai, S.; Miyatake, R.; Saiki, I.; Esumi, H.; Awale, S. (+)-grandifloracin, an antiausterity agent, induces autophagic PANC-1 pancreatic cancer cell death. Drug Des. Devel. Ther. 2014, 8, 39-47. [PubMed]

50. Rasul, A.; Yu, B.; Khan, M.; Zhang, K.; Iqbal, F.; Ma, T.; Yang, H. Magnolol, a natural compound, induces apoptosis of SGC-7901 human gastric adenocarcinoma cells via the mitochondrial and PI3K/Akt signaling pathways. Int. J. Oncol. 2012, 40, 1153-1161. [PubMed]

51. Ruela-de-Sousa, R.R.; Fuhler, G.M.; Blom, N.; Ferreira, C.V.; Aoyama, H.; Peppelenbosch, M.P. Cytotoxicity of apigenin on leukemia cell lines: Implications for prevention and therapy. Cell Death Dis. 2010, 1, e19. [CrossRef] [PubMed]

52. Deng, Q.; Yu, X.; Xiao, L.; Hu, Z.; Luo, X.; Tao, Y.; Yang, L.; Liu, X.; Chen, H.; Ding, Z.; et al. Neoalbaconol induces energy depletion and multiple cell death in cancer cells by targeting PDK1-PI3-K/Akt signaling pathway. Cell Death Dis. 2013, 4, e804. [CrossRef] [PubMed]

53. Jing, Z.; Fei, W.; Zhou, J.; Zhang, L.; Chen, L.; Zhang, X.; Liang, X.; Xie, J.; Fang, Y.; Sui, X.; et al. Salvianolic acid B, a novel autophagy inducer, exerts antitumor activity as a single agent in colorectal cancer cells. Oncotarget 2016, 7, 61509-61519. [CrossRef] [PubMed]

54. Wu, M.; Lao, Y.; Xu, N.; Wang, X.; Tan, H.; Fu, W.; Lin, Z.; Xu, H. Guttiferone K induces autophagy and sensitizes cancer cells to nutrient stress-induced cell death. Phytomedicine 2015, 22, 902-910. [CrossRef] [PubMed]

55. Wang, M.; Yu, T.; Zhu, C.; Sun, H.; Qiu, Y.; Zhu, X.; Li, J. Resveratrol triggers protective autophagy through the ceramide/Akt/mTOR pathway in melanoma B16 cells. Nutr. Cancer 2014, 66, 435-440. [CrossRef] [PubMed]

56. Kaushik, G.; Ramalingam, S.; Subramaniam, D.; Rangarajan, P.; Protti, P.; Rammamoorthy, P.; Anant, S.; Mammen, J.M. Honokiol induces cytotoxic and cytostatic effects in malignant melanoma cancer cells. Am. J. Surg. 2012, 204, 868-873. [CrossRef] [PubMed]

57. Aoki, H.; Takada, Y.; Kondo, S.; Sawaya, R.; Aggarwal, B.B.; Kondo, Y. Evidence that curcumin suppresses the growth of malignant gliomas in vitro and in vivo through induction of autophagy: Role of Akt and extracellular signal-regulated kinase signaling pathways. Mol. Pharmacol. 2007, 72, 29-39. [CrossRef] [PubMed]

58. Wang, W.J.; Wang, Y.; Hou, P.P.; Li, F.W.; Zhou, B.; Chen, H.Z.; Bian, X.L.; Cai, Q.X.; Xing, Y.Z.; He, J.P.; et al. Induction of autophagic death in cancer cells by agonizing TR3 and attenuating Akt2 activity. Chem. Biol. 2015, 22, 1040-1051. [CrossRef] [PubMed]

59. Sun, Q.; Yao, G.D.; Song, X.Y.; Qi, X.L.; Xi, Y.F.; Li, L.Z.; Huang, X.X.; Song, S.J. Autophagy antagonizes apoptosis induced by flavan enantiomers from Daphne giraldii in hepatic carcinoma cells in vitro. Eur. J. Med. Chem. 2017, 133, 1-10. [CrossRef] [PubMed]

60. Yao, Z.; Xie, F.; Li, M.; Liang, Z.; Xu, W.; Yang, J.; Liu, C.; Li, H.; Zhou, H.; Qu, L.H. Oridonin induces autophagy via inhibition of glucose metabolism in p53-mutated colorectal cancer cells. Cell Death Dis. 2017, 8, e2633. [CrossRef] [PubMed]

61. Park, S.; Fudhaili, A.; Oh, S.S.; Lee, K.W.; Madhi, H.; Kim, D.H.; Yoo, J.; Ryu, H.W.; Park, K.H.; Kim, K.D. Cytotoxic effects of kazinol a derived from Broussonetia papyrifera on human bladder cancer cells, T24 and T24R2. Phytomedicine 2016, 23, 1462-1468. [CrossRef] [PubMed]

62. Park, I.J.; Yang, W.K.; Nam, S.H.; Hong, J.; Yang, K.R.; Kim, J.; Kim, S.S.; Choe, W.; Kang, I.; Ha, J. Cryptotanshinone induces G1 cell cycle arrest and autophagic cell death by activating the AMP-activated protein kinase signal pathway in HepG2 hepatoma. Apoptosis 2014, 19, 615-628. [CrossRef] [PubMed]

63. Yun, S.M.; Jung, J.H.; Jeong, S.J.; Sohn, E.J.; Kim, B.; Kim, S.H. Tanshinone IIA induces autophagic cell death via activation of AMPK and ERK and inhibition of mTOR and p70 S6K in KBM-5 leukemia cells. Phytother. Res. 2014, 28, 458-464. [CrossRef] [PubMed]

64. Law, B.Y.; Wang, M.; Ma, D.L.; Al-Mousa, F.; Michelangeli, F.; Cheng, S.H.; Ng, M.H.; To, K.F.; Mok, A.Y.; Ko, R.Y.; et al. Alisol B, a novel inhibitor of the sarcoplasmic/endoplasmic reticulum $\mathrm{Ca}^{2+}$ ATPase pump, induces autophagy, endoplasmic reticulum stress, and apoptosis. Mol. Cancer Ther. 2010, 9, 718-730. [CrossRef] [PubMed]

65. Amini, A.; Masoumi-Moghaddam, S.; Ehteda, A.; Morris, D.L. Bromelain and N-acetylcysteine inhibit proliferation and survival of gastrointestinal cancer cells in vitro: Significance of combination therapy. J. Exp. Clin. Cancer Res. 2014, 33, 92-107. [CrossRef] [PubMed] 
66. Gao, S.; Sun, D.; Wang, G.; Zhang, J.; Jiang, Y.; Li, G.; Zhang, K.; Wang, L.; Huang, J.; Chen, L. Growth inhibitory effect of paratocarpin E, a prenylated chalcone isolated from Euphorbia humifusa wild., by induction of autophagy and apoptosis in human breast cancer cells. Bioorg. Chem. 2016, 69, 121-128. [CrossRef] [PubMed]

67. Rasul, A.; Yu, B.; Zhong, L.; Khan, M.; Yang, H.; Ma, T. Cytotoxic effect of evodiamine in SGC-7901 human gastric adenocarcinoma cells via simultaneous induction of apoptosis and autophagy. Oncol. Rep. 2012, 27, 1481-1487. [PubMed]

68. Li, B.; Takeda, T.; Tsuiji, K.; Wong, T.F.; Tadakawa, M.; Kondo, A.; Nagase, S.; Yaegashi, N. Curcumin induces cross-regulation between autophagy and apoptosis in uterine leiomyosarcoma cells. Int. J. Gynecol. Cancer 2013, 23, 803-808. [CrossRef] [PubMed]

69. She, T.; Qu, L.; Wang, L.; Yang, X.; Xu, S.; Feng, J.; Gao, Y.; Zhao, C.; Han, Y.; Cai, S.; et al. Sarsaparilla (Smilax glabra rhizome) extract inhibits cancer cell growth by $S$ phase arrest, apoptosis, and autophagy via redox-dependent ERK1/2 pathway. Cancer Prev. Res. (Phila) 2015, 8, 464-474. [CrossRef] [PubMed]

70. Yamamoto, M.; Suzuki, S.O.; Himeno, M. Resveratrol-induced autophagy in human U373 glioma cells. Oncol. Lett. 2010, 1, 489-493. [CrossRef] [PubMed]

71. Chun, J.; Kang, M.; Kim, Y.S. A triterpenoid saponin from Adenophora triphylla var. Japonica suppresses the growth of human gastric cancer cells via regulation of apoptosis and autophagy. Tumour Biol. 2014, 35, 12021-12030. [CrossRef] [PubMed]

72. Wang, Z.; Wang, N.; Liu, P.; Chen, Q.; Situ, H.; Xie, T.; Zhang, J.; Peng, C.; Lin, Y.; Chen, J. Microrna-25 regulates chemoresistance-associated autophagy in breast cancer cells, a process modulated by the natural autophagy inducer isoliquiritigenin. Oncotarget 2014, 5, 7013-7026. [CrossRef] [PubMed]

73. Lim, C.B.; Fu, P.Y.; Ky, N.; Zhu, H.S.; Feng, X.; Li, J.; Srinivasan, K.G.; Hamza, M.S.; Zhao, Y. NF-kB p65 repression by the sesquiterpene lactone, helenalin, contributes to the induction of autophagy cell death. BMC Complement Altern. Med. 2012, 12, 93-105. [CrossRef] [PubMed]

74. Garufi, A.; Pistritto, G.; Cirone, M.; D'Orazi, G. Reactivation of mutant p53 by capsaicin, the major constituent of peppers. J. Exp. Clin. Cancer Res. 2016, 35, 136-145. [CrossRef] [PubMed]

75. Afiyatullov, S.S.; Leshchenko, E.V.; Berdyshev, D.V.; Sobolevskaya, M.P.; Antonov, A.S.; Denisenko, V.A.; Popov, R.S.; Pivkin, M.V.; Udovenko, A.A.; Pislyagin, E.A.; et al. Zosteropenillines: Polyketides from the marinederived fungus Penicillium thomii. Mar. Drugs 2017, 15, 46. [CrossRef] [PubMed]

76. Zhang, L.D.; Liu, Z.; Liu, H.; Ran, D.M.; Guo, J.H.; Jiang, B.; Wu, Y.L.; Gao, F.H. Oridonin enhances the anticancer activity of NVP-BEZ235 against neuroblastoma cells in vitro and in vivo through autophagy. Int. J. Oncol. 2016, 49, 657-665. [CrossRef] [PubMed]

77. Filippi-Chiela, E.C.; Villodre, E.S.; Zamin, L.L.; Lenz, G. Autophagy interplay with apoptosis and cell cycle regulation in the growth inhibiting effect of resveratrol in glioma cells. PLoS ONE 2011, 6, e20849. [CrossRef] [PubMed]

78. Rafatian, G.; Khodagholi, F.; Farimani, M.M.; Abraki, S.B.; Gardaneh, M. Increase of autophagy and attenuation of apoptosis by Salvigenin promote survival of SH-SY5Y cells following treatment with $\mathrm{H}_{2} \mathrm{O}_{2}$. Mol. Cell. Biochem. 2012, 371, 9-22. [CrossRef] [PubMed]

79. Dimasi, P.; Quintiero, A.; Shelkovnikova, T.A.; Buchman, V.L. Modulation of p-eIF2 $\alpha$ cellular levels and stress granule assembly/disassembly by trehalose. Sci. Rep. 2017, 7, 44088-44098. [CrossRef] [PubMed]

80. Zhang, Q.C.; Pan, Z.H.; Liu, B.N.; Meng, Z.W.; Wu, X.; Zhou, Q.H.; Xu, K. Benzyl isothiocyanate induces protective autophagy in human lung cancer cells through an endoplasmic reticulum stress-mediated mechanism. Acta. Pharmacol. Sin. 2017, 38, 539-550. [CrossRef] [PubMed]

81. Yang, J.C.; Lu, M.C.; Lee, C.L.; Chen, G.Y.; Lin, Y.Y.; Chang, F.R.; Wu, Y.C. Selective targeting of breast cancer cells through ROS-mediated mechanisms potentiates the lethality of paclitaxel by a novel diterpene, gelomulide k. Free Radic. Biol. Med. 2011, 51, 641-657. [CrossRef] [PubMed]

82. Sun, Z.L.; Dong, J.L.; Wu, J. Juglanin induces apoptosis and autophagy in human breast cancer progression via ROS/JNK promotion. Biomed Pharmacother. 2017, 85, 303-312. [CrossRef] [PubMed]

83. Chen, L.; Meng, Y.; Sun, Q.; Zhang, Z.; Guo, X.; Sheng, X.; Tai, G.; Cheng, H.; Zhou, Y. Ginsenoside compound $\mathrm{K}$ sensitizes human colon cancer cells to TRAIL-induced apoptosis via autophagy-dependent and -independent DR5 upregulation. Cell Death Dis. 2016, 7, e2334. [CrossRef] [PubMed] 
84. Xavier, C.P.; Lima, C.F.; Pedro, D.F.; Wilson, J.M.; Kristiansen, K.; Pereira-Wilson, C. Ursolic acid induces cell death and modulates autophagy through JNK pathway in apoptosis-resistant colorectal cancer cells. J. Nutr. Biochem. 2013, 24, 706-712. [CrossRef] [PubMed]

85. Hung, A.C.; Tsai, C.H.; Hou, M.F.; Chang, W.L.; Wang, C.H.; Lee, Y.C.; Ko, A.; Hu, S.C.; Chang, F.R.; Hsieh, P.W.; et al. The synthetic $\beta$-nitrostyrene derivative CYT-Rx20 induces breast cancer cell death and autophagy via ROS-mediated MEK/ERK pathway. Cancer Lett. 2016, 371, 251-261. [CrossRef] [PubMed]

86. Fu, Y.; Chang, H.; Peng, X.; Bai, Q.; Yi, L.; Zhou, Y.; Zhu, J.; Mi, M. Resveratrol inhibits breast cancer stem-like cells and induces autophagy via suppressing Wnt/ $\beta$-catenin signaling pathway. PLoS ONE 2014, 9, e102535. [CrossRef] [PubMed]

87. Huang, H.; Weng, H.; Dong, B.; Zhao, P.; Zhou, H.; Qu, L. Oridonin triggers chaperon-mediated proteasomal degradation of BCR-ABL in leukemia. Sci. Rep. 2017, 7, 41525. [CrossRef] [PubMed]

88. Tan, H.Y.; Wang, N.; Man, K.; Tsao, S.W.; Che, C.M.; Feng, Y. Autophagy-induced RelB/p52 activation mediates tumour-associated macrophage repolarisation and suppression of hepatocellular carcinoma by natural compound baicalin. Cell Death Dis. 2015, 6, e1942. [CrossRef] [PubMed]

89. Amalraj, A.; Pius, A.; Gopi, S.; Gopi, S. Biological activities of curcuminoids, other biomolecules from turmeric and their derivatives-A review. J. Tradit. Complement Med. 2017, 7, 205-233. [CrossRef] [PubMed]

90. Mirzaei, H.; Shakeri, A.; Rashidi, B.; Jalili, A.; Banikazemi, Z.; Sahebkar, A. Phytosomal curcumin: A review of pharmacokinetic, experimental and clinical studies. Biomed. Pharmacother. 2017, 85, 102-112. [CrossRef] [PubMed]

91. Klinger, N.V.; Mittal, S. Therapeutic potential of curcumin for the treatment of brain tumors. Oxid. Med. Cell. Longev. 2016, 2016, 9324085. [CrossRef] [PubMed]

92. Zhuang, W.; Long, L.; Zheng, B.; Ji, W.; Yang, N.; Zhang, Q.; Liang, Z. Curcumin promotes differentiation of glioma-initiating cells by inducing autophagy. Cancer Sci. 2012, 103, 684-690. [CrossRef] [PubMed]

93. Zhou, G.Z.; Xu, S.L.; Sun, G.C.; Chen, X.B. Novel curcumin analogue IHCH exhibits potent antiproliferative effects by inducing autophagy in A549 lung cancer cells. Mol. Med. Rep. 2014, 10, 441-446. [PubMed]

94. Katkar, K.; Suthar, A.; Chauhan, V. The chemistry, pharmacologic, and therapeutic applications of polyalthia longifolia. Pharmacogn. Rev. 2010, 4, 62-68. [PubMed]

95. Chang, F.R.; Hwang, T.L.; Yang, Y.L.; Li, C.E.; Wu, C.C.; Issa, H.H.; Hsieh, W.B.; Wu, Y.C. Anti-inflammatory and cytotoxic diterpenes from formosan Polyalthia longifolia var. Pendula. Planta Med. 2006, 72, 1344-1347. [CrossRef] [PubMed]

96. Mukherjee, P.K.; Wahile, A. Integrated approaches towards drug development from Ayurveda and other indian system of medicines. J. Ethnopharmacol. 2006, 103, 25-35. [CrossRef] [PubMed]

97. Murphy, M.M.; Subramanyam, M.; Bindu, M.H.; Annapurna, J. Antimicrobial activity of clerodane diterpenoids from polyalthia longifolia seeds. Fitoterapia 2005, 76, 336-339.

98. Sari, D.P.; Ninomiya, M.; Efdi, M.; Santoni, A.; Ibrahim, S.; Tanaka, K.; Koketsu, M. Clerodane diterpenes isolated from polyalthia longifolia induce apoptosis in human leukemia HL-60 cells. J. Oleo. Sci. 2013, 62, 843-848. [CrossRef] [PubMed]

99. Wu, T.H.; Cheng, Y.Y.; Chen, C.J.; Ng, L.T.; Chou, L.C.; Huang, L.J.; Chen, Y.H.; Kuo, S.C.; El-Shazly, M.; $\mathrm{Wu}$, Y.C.; et al. Three new clerodane diterpenes from Polyalthia longifolia var. Pendula. Molecules 2014, 19, 2049-2060. [CrossRef] [PubMed]

100. Shih, Y.T.; Hsu, Y.Y.; Chang, F.R.; Wu, Y.C.; Lo, Y.C. 6-hydroxycleroda-3,13-dien-15,16-olide protects neuronal cells from lipopolysaccharide-induced neurotoxicity through the inhibition of microglia-mediated inflammation. Planta Med. 2010, 76, 120-127. [CrossRef] [PubMed]

101. Lin, Y.H.; Lee, C.C.; Chang, F.R.; Chang, W.H.; Wu, Y.C.; Chang, J.G. 16-hydroxycleroda-3,13-dien-15,16-olide regulates the expression of histone-modifying enzymes PRC2 complex and induces apoptosis in CML K562 cells. Life Sci. 2011, 89, 886-895. [CrossRef] [PubMed]

102. Lin, Y.H.; Lee, C.C.; Chan, W.L.; Chang, W.H.; Wu, Y.C.; Chang, J.G. 16-hydroxycleroda-3,13-dien-15,16-olide deregulates PI3K and Aurora B activities that involve in cancer cell apoptosis. Toxicology 2011, 285, 72-80. [CrossRef] [PubMed]

103. Thiyagarajan, V.; Lin, S.H.; Chia, Y.C.; Weng, C.F. A novel inhibitor, 16-hydroxy-cleroda-3,13-dien-16,15-olide, blocks the autophosphorylation site of focal adhesion kinase (Y397) by molecular docking. Biochim. Biophys. Acta. 2013, 1830, 4091-4101. [CrossRef] [PubMed] 
104. Thiyagarajan, V.; Sivalingam, K.S.; Viswanadha, V.P.; Weng, C.F. 16-hydroxy-cleroda-3,13-dien-16,15-olide induced glioma cell autophagy via ROS generation and activation of p38 MAPK and ERK-1/2. Environ. Toxicol. Pharmacol. 2016, 45, 202-211. [CrossRef] [PubMed]

105. Cheng, M.F.; Lin, S.R.; Tseng, F.J.; Huang, Y.C.; Tsai, M.J.; Fu, Y.S.; Weng, C.F. The autophagic inhibition oral squamous cell carcinoma cancer growth of 16-hydroxy-cleroda-3,14-dine-15,16-olide. Oncotarget 2017, in press.

106. Laatsch, H.; Kellner, M.; Weyland, H. Butyl-meta-cycloheptylprodiginine-A revision of the structure of the former ortho-isomer. J. Antibiot. (Tokyo) 1991, 44, 187-191. [CrossRef] [PubMed]

107. Chang, C.C.; Chen, W.C.; Ho, T.F.; Wu, H.S.; Wei, Y.H. Development of natural anti-tumor drugs by microorganisms. J. Biosci. Bioeng. 2011, 111, 501-511. [CrossRef] [PubMed]

108. Marchal, E.; Smithen, D.A.; Uddin, M.I.; Robertson, A.W.; Jakeman, D.L.; Mollard, V.; Goodman, C.D.; MacDougall, K.S.; McFarland, S.A.; McFadden, G.I.; et al. Synthesis and antimalarial activity of prodigiosenes. Org. Biomol. Chem. 2014, 12, 4132-4142. [CrossRef] [PubMed]

109. Lapenda, J.C.; Silva, P.A.; Vicalvi, M.C.; Sena, K.X.; Nascimento, S.C. Antimicrobial activity of prodigiosin isolated from Serratia marcescens UFPEDA 398. World J. Microbiol. Biotechnol. 2015, 31, 399-406. [CrossRef] [PubMed]

110. Wang, Y.; Nakajima, A.; Hosokawa, K.; Soliev, A.B.; Osaka, I.; Arakawa, R.; Enomoto, K. Cytotoxic prodigiosin family pigments from pseudoalteromonas sp. 1020R isolated from the pacific coast of Japan. Biosci. Biotechnol. Biochem. 2012, 76, 1229-1232. [CrossRef] [PubMed]

111. Kimyon, O.; Das, T.; Ibugo, A.I.; Kutty, S.K.; Ho, K.K.; Tebben, J.; Kumar, N.; Manefield, M. Serratia secondary metabolite prodigiosin inhibits pseudomonas aeruginosa biofilm development by producing reactive oxygen species that damage biological molecules. Front Microbiol. 2016, 7, 972-987. [CrossRef] [PubMed]

112. Song, Y.; Liu, G.; Li, J.; Huang, H.; Zhang, X.; Zhang, H.; Ju, J. Cytotoxic and antibacterial angucyclineand prodigiosin-analogues from the deep-sea derived streptomyces sp. Scsio 11594. Mar. Drugs 2015, 13, 1304-1316. [CrossRef] [PubMed]

113. Kancharla, P.; Lu, W.; Salem, S.M.; Kelly, J.X.; Reynolds, K.A. Stereospecific synthesis of 23-hydroxyundecylprodiginines and analogues and conversion to antimalarial premarineosins via a rieske oxygenase catalyzed bicyclization. J. Org. Chem. 2014, 79, 11674-11689. [CrossRef] [PubMed]

114. Perez-Tomas, R.; Vinas, M. New insights on the antitumoral properties of prodiginines. Curr. Med. Chem. 2010, 17, 2222-2231. [CrossRef] [PubMed]

115. Sam, S.; Sam, M.R.; Esmaeillou, M.; Safaralizadeh, R. Effective targeting survivin, caspase-3 and microrna-16-1 expression by methyl-3-pentyl-6-methoxyprodigiosene triggers apoptosis in colorectal cancer stem-like cells. Pathol. Oncol. Res. 2016, 22, 715-723. [CrossRef] [PubMed]

116. Yu, C.J.; Ou, J.H.; Wang, M.L.; Jialielihan, N.; Liu, Y.H. Elevated survivin mediated multidrug resistance and reduced apoptosis in breast cancer stem cells. J. BUON 2015, 20, 1287-1294. [PubMed]

117. Papireddy, K.; Smilkstein, M.; Kelly, J.X.; Salem, S.M.; Alhamadsheh, M.; Haynes, S.W.; Challis, G.L.; Reynolds, K.A. Antimalarial activity of natural and synthetic prodiginines. J. Med. Chem. 2011, 54, 5296-5306. [CrossRef] [PubMed]

118. Chang, C.C.; Wang, Y.H.; Chern, C.M.; Liou, K.T.; Hou, Y.C.; Peng, Y.T.; Shen, Y.C. Prodigiosin inhibits gp91 ${ }^{\text {phox }}$ and iNOS expression to protect mice against the oxidative/nitrosative brain injury induced by hypoxia-ischemia. Toxicol. Appl. Pharmacol. 2011, 257, 137-147. [CrossRef] [PubMed]

119. Dalili, D.; Fouladdel, S.; Rastkari, N.; Samadi, N.; Ahmadkhaniha, R.; Ardavan, A.; Azizi, E. Prodigiosin, the red pigment of Serratia marcescens, shows cytotoxic effects and apoptosis induction in HT-29 and T47D cancer cell lines. Nat. Prod. Res. 2012, 26, 2078-2083. [PubMed]

120. Hassankhani, R.; Sam, M.R.; Esmaeilou, M.; Ahangar, P. Prodigiosin isolated from cell wall of Serratia marcescens alters expression of apoptosis-related genes and increases apoptosis in colorectal cancer cells. Med. Oncol. 2015, 32, 366-374. [CrossRef] [PubMed]

121. Hong, B.; Prabhu, V.V.; Zhang, S.; van den Heuvel, A.P.; Dicker, D.T.; Kopelovich, L.; El-Deiry, W.S. Prodigiosin rescues deficient p53 signaling and antitumor effects via upregulating p73 and disrupting its interaction with mutant p53. Cancer Res. 2014, 74, 1153-1165. [CrossRef] [PubMed]

122. Krishna, P.S.; Vani, K.; Prasad, M.R.; Samatha, B.; Bindu, N.S.; Charya, M.A.; Shetty, P.R. In-silico molecular docking analysis of prodigiosin and cycloprodigiosin as COX-2 inhibitors. Springerplus 2013, 2, 172-178. [CrossRef] [PubMed] 
123. Hosseini, A.; Espona-Fiedler, M.; Soto-Cerrato, V.; Quesada, R.; Perez-Tomas, R.; Guallar, V. Molecular interactions of prodiginines with the BH3 domain of anti-apoptotic Bcl-2 family members. PLoS ONE 2013, 8, e57562. [CrossRef] [PubMed]

124. Elahian, F.; Moghimi, B.; Dinmohammadi, F.; Ghamghami, M.; Hamidi, M.; Mirzaei, S.A. The anticancer agent prodigiosin is not a multidrug resistance protein substrate. DNA Cell Biol. 2013, 32, 90-97. [CrossRef] [PubMed]

125. Pan, M.Y.; Shen, Y.C.; Lu, C.H.; Yang, S.Y.; Ho, T.F.; Peng, Y.T.; Chang, C.C. Prodigiosin activates endoplasmic reticulum stress cell death pathway in human breast carcinoma cell lines. Toxicol. Appl. Pharmacol. 2012, 265, 325-334. [CrossRef] [PubMed]

(C) 2017 by the authors. Licensee MDPI, Basel, Switzerland. This article is an open access article distributed under the terms and conditions of the Creative Commons Attribution (CC BY) license (http:/ / creativecommons.org/licenses/by/4.0/). 